\title{
筋エコーにより筋炎の関与が判明した右房拡張症の一例
}

宮崎由道高松直子宮城愛寺澤由佳松井尚子浅沼光太郎和泉唯信

梶 龍兒

徳島大学病院神経内科

\section{A case of enlargement of the right atrium associated with myositis detected by muscle ultrasonography}

\author{
Yoshimichi MIYAZAKI, Naoko TAKAMATSU, Ai MIYASHIRO, Yuka TERASAWA, Naoko MATSUI, Koutaro ASANUMA, \\ Yuishin IZUMI, and Ryuji KAJI
}

Department of Neurology, Tokushima University

\begin{abstract}
A 45-year-old woman was admitted because of general malaise. Analysis of her family history revealed that one of her older sisters had died of ulcerative colitis, another sister had systemic lupus erythematosus, and her elder brother had Behcet's disease.

Electrocardiography demonstrated atrial fibrillation associated with marked dilation of the right atrium. Ultrasonography of the biceps brachii showed a marked myopathic pattern. A biopsy specimen obtained from the biceps brachii, revealed degeneration and necrosis of the muscle fibers, interstitial infiltration of monocytes, and perivascular infiltration of inflammatory cells. Magnetic resonance imaging of the heart showed marked dilation of the right atrium, as well as diffuse high-intensity areas in the left ventricle in T2-weighted images.

We diagnosed the patient as having generalized myositis associated with myocarditis, and administered steroid therapy. One year later, the patient is still receiving steroid therapy and showing continuous improvement of her symptoms.

If a patient shows enlargement of one of the cardiac atria or ventricles, the possibility of cardiac or systemic myositis should be considered. In such cases, skeletal muscle ultrasonography may be a useful non-invasive modality for differential diagnosis.
\end{abstract}

Key Words : atrial dilation, myositis, ultrasonography

\section{はじめに}

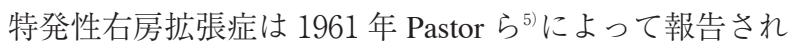
た，原因不明の著明な右房の拡張をきたすきわめてまれな 疾患である。今回われわれは筋エコーにより全身性の筋炎 の合併が判明し，ステロイドに対し治療反応性を認めた右 房拡張症の 1 例を経験したので報告する。

\section{症例}

患者: 45 歳女性.

職業：看護師.

主訴：全身倦怠感.

家族歴：兄がBehçet 病、長姉が全身性エリテマトーデス、次 姉が潰瘍性大腸炎 (死亡).

既往歴：特記事項なし。

現病歴：42 歳の頃より動悸症状を自覚，44 歳時には全身倦
总感を強く自覚するようになった。近医の心電図にて心房 細動を指摘されたため，精査目的にて当院に入院した.

入院時現症：一般身体所見：身長 $158.5 \mathrm{~cm}$, 体重 $57.1 \mathrm{~kg}$ 体温 $36.8^{\circ} \mathrm{C}$ 脈拍 54 回/分・整, 血圧 $117 / 66 \mathrm{mmHg}$ 貧血・黄 疸なく浮腫も認めなかった。聴診では心雑音や過剩心音は なく, 肺音は清, 頸動脈雑音も認めなかった.

神経学的所見：頸部，四肢近位部にごく軽度の筋力低下を 認めた．Gowers 徵候は明らかでなかった。その他の神経学 的所見に特記事項はなかった。

検查所見：血液検査では GOT 36IU/1, CK 597IU/1 (CKMB 4\%, CK-MM 96\%，CK-BB 0\%）と筋原性酵素の 軽度増加を認めた. WBC $7900 / \mu 1$, CRP $0.10 \mathrm{mg} / \mathrm{dl}$. 抗核抗 体 80 倍. 抗 ds-DNA 抗体, 抗 RNP 抗体, 抗 SS-B 抗体, 抗 Jo-1 抗体はいずれも陰性. ACE は $11.4 \mathrm{IU} / 1$ と正常範囲内で あった. 24 時間心電図検査では頻発する発作性心房細動を 認め，またモニター心電図にて最大約 7 秒の洞停止を確認

Reprint request

宮崎由道 : = 770-8503 徳島県徳島市蔵本町 2 丁目 50-1 徳島大学病院神経内科

Yoshimichi MIYAZAKI : Department of Neurology Tokushima University, 50-1, kuramoto-cho, Tokushima-city, 770-8503, Japan

Tel : +81-88-633-7207 Fax : +81-88-633-7208 E-mail address : miyazaki@clin.med.tokushima-u.ac.jp

[Received : Feb, 28, 2011, Accepted : July, 11, 2011] 


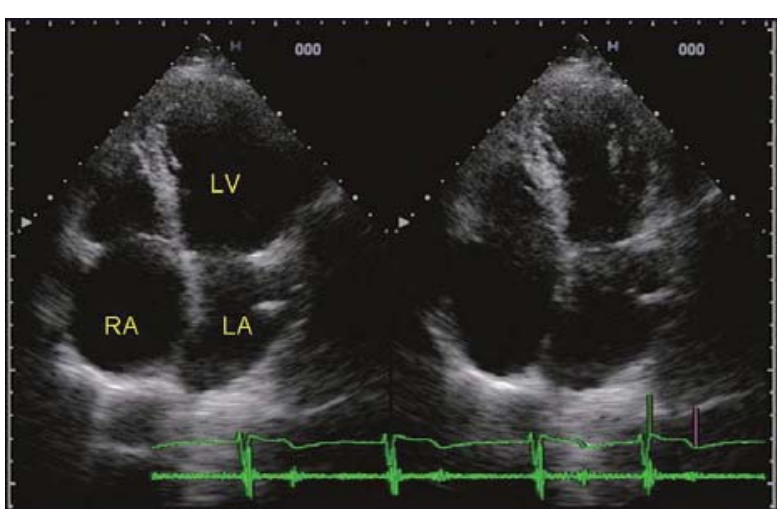

Figure 1 Echocardiogram

Remarkable dilation of the right atrium no abnormal findings are seen in any of the ventricles.

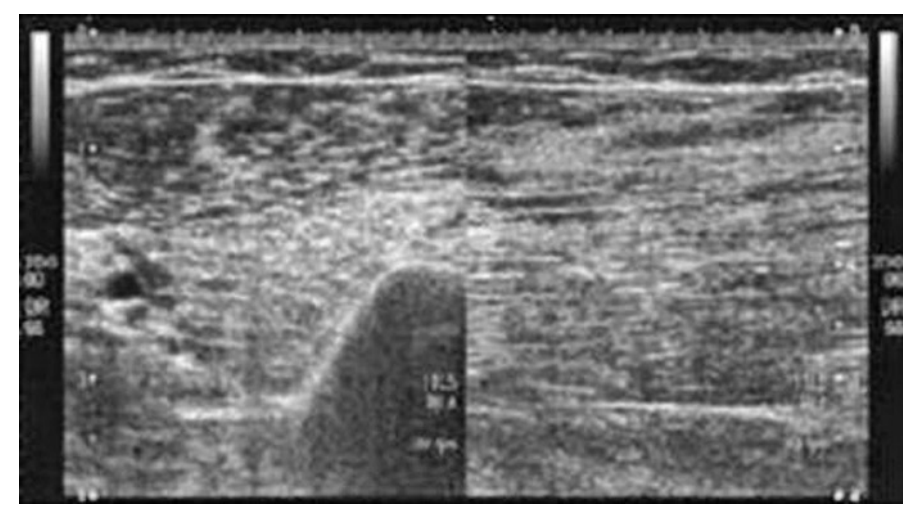

Figure 2 Muscle ultrasonography from the biceps brachii

Echo intensities are heterogeneously high, and degeneration of muscle fibers is suspected.

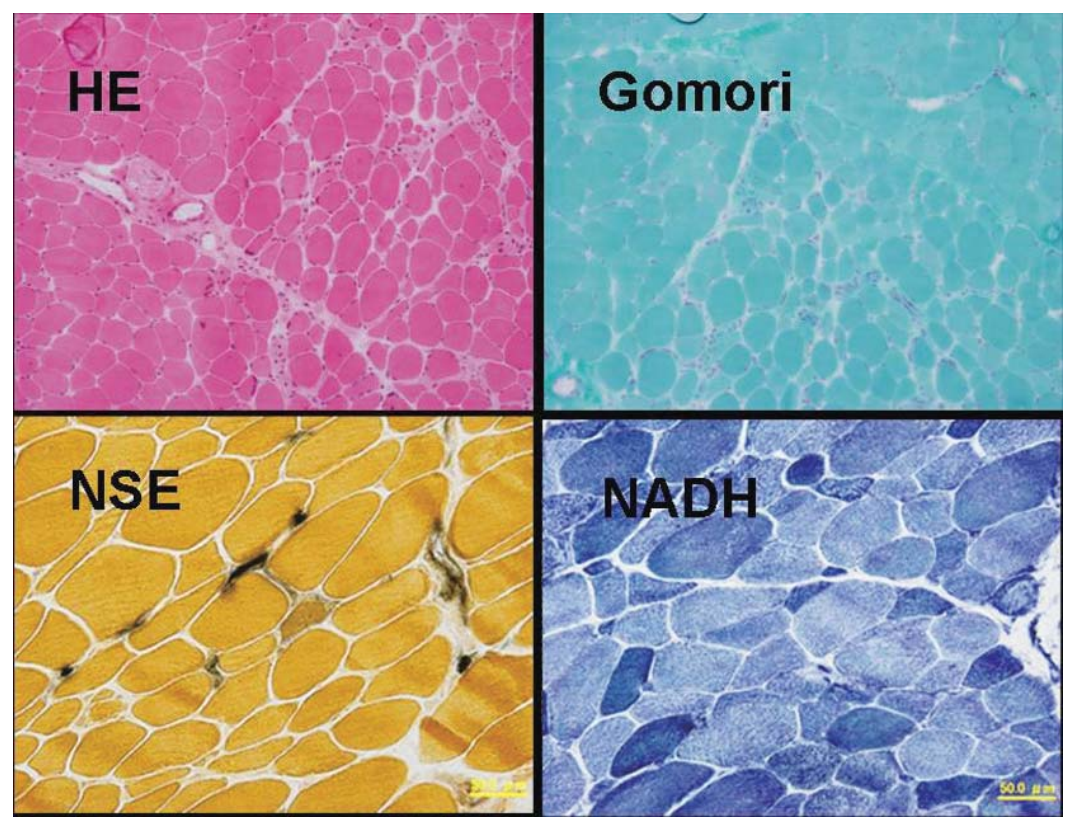

Figure 3 Biopsy specimen obtained from the biceps brachii

HE $[\times 125]:$ The muscles show degeneration and necrosis of muscle fibers, interstitial infiltration of monocytes, and perivascular infiltration of inflammatory cells.

Gomori $[\times 125]$ : Several ragged-red fibers are observed.

NSE/NADH $[\times 300]$ : Abnormal findings are not seen.

した。心エコー（Fig.1）では右房の著明な拡張と左房の軽 度拡張を認めた。三尖弁に軽度逆流を認めたが, 逆流の程 度からは右房拡張の直接原因とは考元難かった，僧帽弁に 異常は認めず，左室収縮能は保たれていた。

特発性右房拡張症が疑われたが，家族歴から膠原病類縁 疾患による心筋症なども考えられ，鑑別目的にて筋エコー 検查を施行した。 上腕二頭筋を含めた複数の筋にてエコー 輝度の上昇と所々に粗雑な筋線維の変性が疑われ, 筇炎の 存在が示唆された (Fig. 2). 診断確定のため上腕二頭筋より 筋生検を施行した。横紋筋線維に軽度の大小不同あり, 一 部に炎症細胞浸潤を認めた（Fig. 3)。心筋を含む全身性筋炎 の可能性が強く示唆されたため心臟造影 MRI 検查を実施，T2 強調画像にて左室心筋はびまん性に high intensity であり, ガ
ドリニウム遅延造影にて T2 high lesionに合致した造影効果 を認め，心筋炎の存在が示された．以上の検査結果から心 房優位の心筋炎を合併した全身性筋炎と診断した。

治療経過：最大約 7 秒の洞停止がみられ突然死の可能性を 考慮し，VVIペースメーカー植え込み術を施行した。全身 状態安定ののち，全身性筋炎に対しステロイドパルス療法 (メチルプレドニゾロン $1000 \mathrm{mg} /$ 日) 3 日間施行，その後プ レドニゾロン内服を $50 \mathrm{mg} /$ 隔日にて開始, 漸減し $20 \mathrm{mg} /$ 隔 日投与とした。 ステロイド治療後より頸部や四肢近位部の 軽度の筋力低下は改善を認め, またペースメーカーによる 律動も一旦はほぼ消失していた，全身倦总感も改善したが， ステロイド長期投与によるうつ症状が出現，また漸減に伴 いペースメーカーによる律動も再度出現し, 治療後約 1 年 
後にはペースメーカーによる律動が主体となった。ステロ イド増量も考慮したが，うつ症状が強いため増量は行わず, 隔日投与から連日投与に変更，プレドニゾロン $10 \mathrm{mg} /$ 日で の投与を続けている。

\section{考察}

特発性右房拡張症は原因となる明らかな器質的疾患がな く著明な右房拡張をきたすきわめてまれな疾患で, 本邦で は 1962 年 Saigusa らが最初に報告している

これまでの報告からは, 発症年齢は幼年期から高齢期ま でと幅広くみられ，また明らかな家族内発症例を認める場 合もある ${ }^{1,4-8)}$. 予後は良好な例が多いとされているが，心房 停止や心不全死をきたした例なども報告されており，さま ざまである。組織学的検討では，右心房壁内に細胞浸潤を 認めない非特異的所見を呈するものから，細胞浸潤や心筋 細胞の変性・核の大小不同など心筋炎や心筋症と類似した 所見を示す症例まで様々な症例が報告されている。

本例は，筋エコーにて四肢筋群に筋炎の所見を認め, 上 腕二頭筋での筋生検にて軽度の筋線維の大小不同や一部筋 線維間に炎症細胞浸潤を確認できたこと，また心蔵 MRI 検査で心筋炎が疑われたこと，ステロイド治療で不整脈に 対しても反応性が見られたことから，全身性筋炎に伴い心 筋炎を呈し右房拡張を来したと考えられた。全身性筋炎に 伴った右心房拡張症としては, 皮膚筋炎に伴って発症した 症例が 1 例のみ報告されている ${ }^{8)}$. その報告例においてもぺー スメーカー植え込み時は四肢の筋力低下はなく, 数年の経 過ののち筋力低下をきたしたとされており，本例と同様に 不整脈や全身倦总感などの症状出現時では全身性筋炎を疑 う症状に乏しかったと考えられる。特発性右房拡張症の中 に全身性筋炎に伴う心筋炎を原因とした一群が存在する可 能性がある。

今回われわれは膠原病関連疾患としての筋炎やサルコイ ドーシスなどの鑑別目的に，筋エコー検査を施行した。筋 疾患に対する超音波検査の試みは 1980 年代より報告が見ら $れ^{3)}$, 以来多数の神経筋疾患に対する研究が報告され, その 有用性は確立されつつある。筋疾患の診断に関して，他の 非侵襲的検査法としては CT や MRI があるが2), 情報量の多 いMRI はペースメーカー導入後は施行できず，またCT
も被曝の点から繰り返しの施行には注意が必要である。そ ういった点で筋エコー検査は経過観察の点からも有用と考 えられた。

\section{結語}

特発性右房拡張症の中に全身性筋炎に伴う心筋炎を原因 とした一群が存在する可能性があり，そのスクリーニング 検査として筋エコー検査は侵襲性が少なく簡便であり，ま たペースメーカー導入後も使用できるため有用である.

本症例の要旨は第 29 回日本神経超音波学会総会（2010 年 7 月 9 日，岡山）で発表した。

\section{文 献}

1) Arao M, Shimizu S, Miyatake $Y$, Setsuta $K$ : An autopsy case of familial idiopathic dilatation of bilateral atria. Intern Med 38 : 633-637, 1999

2) Fujino H, Kobayashi T, Goto I, Onitsuka H : Magnetic resonance imaging of the muscles in patients with polymyositis and dermatomyositis. Muscle Nerve $14: 716^{-}$ 720, 1991

3) Heckmatt JZ, Dubowitz V, Leeman S: Detection of pathological change in dystrophic muscle with B scan ultrasound imaging. Lancet1 : 1389-1390, 1980

4) Marin-Garcia J : Idiopathic dilation of the right atrium. Chest $79: 378-379,1981$

5) Pastor BH, Forte AL : Idiopathic enlargement of the right atrium. Am J Cardiol 8:513-518, 1961

6) Saigusa M, Morimoto K, Koike T, Hori T, Sato T: Idiopathic enlargement of the right atrium. Jpn Heart J $3: 373^{-}$ 379, 1962

7) Sheldon WC, Johnson CD, Favaloro RG: Idiopathic enlargement of the right atrium, report of four cases. AmJ Cardiol 23 : 278-284, 1969

8) Terada Y, Mitsui T, Yamamoto T: Enlargement of the right atrium associated with dermatomyositis. Ann Thorac Surg 59 : 263-264, 1995 